Schäfer, A.I. ; Fane, A.G. ; Waite, T.D. (2001) Cost Factors and Chemical Pretreatment Effects in the Membrane Filtration of Waters containing Natural Organic Matter, Water Research 35, 6 , $1509-1517$. doi:10.1016/S0043-1354(00)00418-8

\section{Cost Factors and Chemical Pretreatment Effects in the Membrane Filtration of Waters containing \\ Natural Organic Matter}

\section{A.I. Schäfer ${ }^{1,2, *}$, A.G. Fane ${ }^{2}$, T.D. Waite ${ }^{1}$}

1 Centre for Water and Waste Technology, Civil and Environmental Engineering, University of New South Wales, Sydney, NSW 2052, Australia (*corresponding author)

A.Schaefer@unsw.edu.au, ph++61 29385 4470,fax ++61 293856139

D.Waite@unsw.edu.au, ph ++61 29385 5060, fax ++61 293856139

UNESCO Centre for Membrane Science and Technology, Chemical Engineering, University of New South Wales, Sydney, NSW 2052, Australia

T.Fane@unsw.edu.au, ph ++61 29385 4315, fax ++61 293855966

\section{ABSTRACT}

This paper compares the membrane processes available for water treatment. Membranes have the advantage of currently decreasing capital cost, a relatively small footprint compared to conventional treatment, generally a reduction in chemicals usage and comparably low maintenance requirements.

Three membrane processes applicable to water treatment, micro- (MF), ultra- (UF), and nanofiltration (NF), are compared in terms of intrinsic rejection, variation of rejection due to membrane fouling and increase in rejection by ferric chloride pretreatment. Twelve different membranes are compared on the basis of their membrane pore size which was calculated from their molecular weight cut-off.

A pore size of $<6 \mathrm{~nm}$ is required to achieve substantial $(>50 \%)$ organics removal. For a fouled membrane this pore size is about $11 \mathrm{~nm}$. UV rejection is higher than DOC rejection. Coagulation pretreatment allows a higher rejection of organics by MF and UF and the cut-off criterion due to initial membrane pore size is no longer valid.

A water quality parameter (WQP) is introduced which describes the product water quality achieved as a function of colloid, DOC and cation rejection. The relationship between log (pore size) and WOP is linear.

Estimation of membrane costs as a function of WQP suggests that open UF is superior to MF (similar cost at higher WQP) and NF is superior to tight UF. Chemical pretreatment could (similar cost at higher WQP) and NF is superior to tight UF. Chemical pretreatment could
compensate for the difference between MF and UF. However, when considering chemicals and compensate for the difference between MF and UF. However, when considering chemicals and
energy costs, it appears that a process operated at a higher energy is cheaper at a guaranteed product quality (less dependent on organic type). This argument is further supported by environmental issues of chemicals usage, as energy may be provided from renewable sources.

\section{KEYWORDS}

Coatation, microfiltration (MF), nanofiltration (NF), natural organic matter (NOM), ultrafiltration (UF), water quality parameter (WQP)

\section{INTRODUCTION}

Membrane processes for surface water treatment are microfiltration (MF), ultrafiltration (UF) and nanofiltration (NF), depending on the target material to be removed and the limiting process economics

MF will remove turbidity (particulates and bacteria), but no dissolved compounds, unless associated with colloids. UF will, depending on the molecular weight cut off (MWCO), remove natural organic matter (NOM) partially and viruses. NF will remove NOM and hardness almost completely, but for a price often considered as uneconomic due to capital and energy costs.

Chemical addition prior to MF or UF enhances the NOM removal capacity of these processes to a level comparable to that achieved with NF.

In this paper a process comparison is carried out. Key issues are the organics rejection as a function of estimated pore diameter, the variation of rejection with fouling and coagulation pretreatment and membrane cost as a function of a water quality parameter (WQP). The WQP was defined in terms of colloid, organics and cation rejection.

\section{MATERIALS AND METHODS}

\subsection{Membrane Filtration}

Experiments were carried out in a stirred cell apparatus which has previously been described and characterised in detail (Schäfer et al. (1998)).

Membranes used were commercially available hydrophilic flat sheet MF (GVWP, Millipore, Australia), UF (MWCO 1, 3, 5, 10, 30, $100 \mathrm{kDa}$; regenerated cellulose, Millipore, Australia) and NF (TFC-SR, TFC-S, TFC-ULP, CA-UF, Fluid Systems (now Koch Membrane Systems), San Diego, U.S.) membranes which show minimal adsorption of NOM. Information for membrane costs were received from the Water Factory 21, Orange County, US and not adapted from the cost of membranes purchased for this study.

\section{Chemicals and Natural Organics}

Chemicals were purchased from Ajax Chemicals (Australia) and were all of analytical grade. MilliQ water with a quality of $>18 \mathrm{M} \Omega / \mathrm{cm}$ was used for all experiments.

Organics were purchased from the International Humic Substances Society (IHSS) as Suwannee River fulvic (FA) and humic (HA) acids. Further, NOM was concentrated from a local source using $\mathrm{MF}$ and reverse osmosis (RO). This NOM was further fractionated into humic, fulvic and hydrophilic fractions using ion exchange resins (Schäfer (1999)).

\subsection{Solution Composition}

If not indicated otherwise, a background solution of $20 \mathrm{mM} \mathrm{NaCl}, 1 \mathrm{mM} \mathrm{NaHCO}$ and $0.5 \mathrm{mM}$ $\mathrm{CaCl}_{2}$ was used. For MF the calcium concentration was $2.5 \mathrm{mM}$. Organic concentration ranged from 5 to $12.5 \mathrm{mgL}^{-1}$ as DOC. The $\mathrm{pH}$ was normally between 7 and 8 determined by the carbonate buffer of the background solution.

If colloids were present, their concentration was $10 \mathrm{mgL}^{-1}$ as hematite $\left(\boldsymbol{-}-\mathrm{Fe}_{2} \mathrm{O}_{3}\right)$. Hematite colloids were monodispersed and spherical and sizes of 40, 75, 250 and $500 \mathrm{~nm}$ were produced for this study.

Solution composition is tabulated in Table 1.

\subsection{Ferric Chloride}

Ferric chloride was used as the coagulant. Concentrations were adapted from enhanced coagulation as 25 and $100 \mathrm{mgL}^{-1}$ (Crozes (1995)). Solutions were coagulated in jar testing equipment and filtered without settling of the flocs. $\mathrm{pH}$ was not adjusted at $25 \mathrm{mg}^{-1}$, whe at $100 \mathrm{mg}^{-1}$ the final $\mathrm{pH}$ experiments were conducted with both, solutions at $\mathrm{pH} 3$ and solutions readjusted to $\mathrm{pH} 7-8$. 
Schäfer, A.I. ; Fane, A.G. ; Waite, T.D. (2001) Cost Factors and Chemical Pretreatment Effects in the Membrane Filtration of Waters containing Natural Organic Matter, Water Research 35, 6 , $1509-1517$.

The ferric chloride cost range was provided by Orica Watercare, Australia. The large range of costs was explained with variations in purity and delivery costs depending on the location of the facility. The effect of coagulant purity on membrane performance is unknown.

\subsection{Analytical}

Dissolved organic carbon (DOC) was analysed using a Skalar 12 (Skalar, The Netherlands) instrument.

Ultraviolet/visible absorption was analysed with a Varian Cary 1E spectrophotometer. While samples were scanned from 190 to $500 \mathrm{~nm}$, the results at $254 \mathrm{~nm}$ were used for calculations.

Cation concentration was determined with a Perkin Elmer Optima 3000 spectrometer.

Sample vials were cleaned with $1 \mathrm{M} \mathrm{NaOH}$ and $1 \mathrm{M} \mathrm{H}_{2} \mathrm{SO}_{4}$ solutions to remove organic and inorganic contamination, respectively.

\section{RESULTS AND DISCUSSION}

Membrane Characteristics

Twelve membranes were used in this study. The membranes were characterised by pure water flux and permeability, membrane resistance, molecular weight cut-off (as supplied by the manufacturers) and a calculated pore diameter (Table 2). The pore size calculations are based on an equation determined by Worch (1993) and the Stokes Einstein equation (see Schäfer (1999) for calculations and characterisation of surface roughness, contact angle and charge of the membranes used).

\section{Rejection Characteristics of Clean Membranes}

Rejection characteristics of all membranes were studied in detail and published elsewhere (Schäfer et al. (1999), Aoustin et al. (2000), Schäfer et al. (2000)). In this section the results obtained with the individual processes are summarised and illustrated as a function of calculated membrane pore size.

Figure 1 shows the rejection of DOC as a function of membrane pore size for various organic fractions. A clear cut-off can be seen where rejection drops from about $80 \%$ to $10 \%$. This cut-off is around a pore size of $6 \mathrm{~nm}$. The various organics are retained to a different extent depending on their size. The organics were characterised in detail elsewhere (Schäfer (1999)). Sizes were determined to be 1.6 to $2.7 \mathrm{~nm}$ as equivalent sphere diameters.

Comparing DOC to UV rejection, a higher rejection of UV absorbing compounds is observed (see Figure 2). This indicates a preferential removal of larger and more aromatic compounds over the entire range of membrane pore sizes.

Cation rejection is shown in Table 3. Only the NF membranes remove sodium. Calcium rejection increases gradually with decrease in pore size. Substantial removal is only achieved with the TFC membranes.

The rejection and membrane characterisation results indicate that for each application (and desired product quality) there will be an optimal membrane, which can be selected yielding highest flux and acceptable rejection for the contaminant of concern.

\section{Rejection Characteristics of Fouled Membranes}

Fouling changes the surface characteristics and pore size of membranes and these changes have an impact on the rejection behaviour. Figure 3 compares the organics rejection by fouled membranes with that of clean membranes as shown in Figure 1.

The cut-off where rejection of natural organics drops is shifted from about 6 to $11 \mathrm{~nm}$ due to fouling. The fouling layer consists of a deposit formed with calcium and IHSS HA as previously described (Schäfer et al. (1998)). Childress and Elimelech (1996) have reported a more negative membrane surface charge due to the deposition or adsorption of organics in the presence of calcium. This more negative surface charge may increase the rejection of the generally negatively charged natural organics.

Further, calcium causes the aggregation of organics and subsequent pore size reduction due to the deposition of aggregates. Both of these effects would also enhance organics rejection.

\section{Rejection Characteristics with Coagulation $\left(\mathrm{FeCl}_{3}\right)$ Pretreatment}

In MF and UF, where the pore sizes are larger than the cut-off required to remove a substantial amount of organics $(6 \mathrm{~nm})$, rejection can be increased by coagulant addition.

The coagulant, in this case ferric chloride $\left(\mathrm{FeCl}_{3}\right)$, precipitates and adsorbs natural organics on the precipitate surface. The particulates are subsequently retained which leads to an increased rejection of organics. The extent of increased removal is shown in Figure 4 for three types of organics and two ferric chloride dosages. The coagulant dosages are typical of those used in enhanced coagulation applications (Crozes (1995)).

The natural organics removal is higher for the higher coagulant dose and can reach levels similar to those of the small pore size membranes. However, the low rejection at low ferric chloride concentrations and the large scatter in data with organic type indicate that the removal is dependent on the water characteristics and thus potentially subject to considerable variation during water treatment.

\section{Membrane Fouling Behaviour and Influence of Coagulation}

In MF and UF, coagulation is used as a means of increasing natural organics rejection. The organics are adsorbed on a ferric oxyhydroxide precipitate which is retained by the membrane. This precipitated colloid can cause membrane fouling by pore blocking or cake deposition, a mechanism which depends on the membrane pore size and the conditions under which the precipitates are formed.

Flux ratios $\left(J / J_{0}\right.$ is the ratio of flux to initial flux) over permeate volume are shown in Figure 5 and Figure 6 for MF and UF, respectively. Flux decreases with increasing ferric chloride dosage and the more open the membrane the larger is the effect. This is because the more open membrane with higher $\mathrm{J}_{0}$ appears to be more sensitive to cake formation.

In NF, natural organics rejection is high and no coagulation pretreatment is required. However, since coagulation targets large, hydrophobic organics which foul NF membranes by precipitation and gel layer formation, coagulation pretreatment can control fouling.

This effect is shown in Figure 7, where $J / J_{0}$ is the ratio of permeate flux to flux at the beginning of the experiment. The flux declines rapidly and irreversibly without coagulation. If ferric chloride is added flux decline ceases. 
This pretreatment effects the fouling and with the alteration of the deposit, also the rejection of the membrane. The foulant is bound to precipitates which are too large to foul the NF membranes. This pretreatment also modifies the rejection of solutes by a variation of the surface charge of the organic Organic rejection decreases from $93 \%$ to $79 \%$ at $\mathrm{pH} 3$ where a very positively charged precipitate is formed. The rejection of calcium generally increases from $55 \%$ to almost $99 \%$ at $\mathrm{pH} 3$, while sodium rejection increases from 24 to $43 \%$ at these conditions (for details on these results see Schäfer (1999)).

\section{Water Quality Parameter (WQP)}

Fane (1996) proposed an overall water quality index for treatment based on pathogen, turbidity, colour and salt removal. This criterion was modified to suit the study in this project and is presented in Table 4.

Pathogens were not included in this study as $100 \%$ removal is assumed. However, for MF this may not be achieved under all operating conditions as reported by Jacangelo et al. (1995). Log removals of the virus MS2 bacteriophages $(0.025 \mu \mathrm{m})$ reported were as low as $0.4(60 \%)$ for MF $(0.2 \mu \mathrm{m})$ while a UF membrane (100 kDa) removed $>6$ log. Cryptosporidium parvum (4 to $6 \mu \mathrm{m}$ in diameter) and Giardia muris ( 7 to $14 \mu \mathrm{m}$ ) cysts removal was complete ( $>6$ log, below detection limit) by both MF and UF. The removal of viruses is thus a criterion which needs to be considered in the process choice. Log removal describes the number of orders of magnitude by which the feed concentration is removed and is defined as $\log _{10}$ (feed concenmtration / permeate concentration) (Ho and Sirkar (1992)).

As a sum criterion, the water quality parameter (WQP) is introduced. The maximum score for WQP is 300 . The total score for each parameter suite (colloids, DOC, and ions) is 100. The columns are subdivided into equal fractions, resulting in total points of 25 for the individual colloid fraction, 33.3 for each organic fraction, and 50 for the major cations $\left(\mathrm{Na}^{+}, \mathrm{Ca}^{2+}\right)$.

For colloids, stable primary colloids (in our other work described as " organic-particle-salt (OPS) systems"- colloids which are stabilised by organics) are assumed as these appear most abundant in natural waters. These colloidal systems are described in detail elsewhere (Schäfer et al. (1999)).

Ion rejection is represented by sodium and calcium rejection in the absence of organics. In the case of DOC rejection, solutions contain $0.5 \mathrm{mM} \mathrm{CaCl}_{2}$ (except for $\mathrm{MF}$ where calcium concentration is $2.5 \mathrm{mM})$.

The WQP values increase with membrane tightness as expected. The relationship between log (pore size) and WQP is linear (Figure 8). The CA-UF membrane performs overall as a UF membrane in the $5 \mathrm{kDa}$ cut-off range.

MF and UF membranes with a MWCO above $10 \mathrm{kDa}$ achieve a WQP below 150 (i.e. only 50\% of the maximum score) while the NF membranes achieve values in the range 230 to 280 .

Under fouling conditions, the WQP is only slightly modified. Values are presented in

Table 5. For the UF membranes with a pore size close to the cut-off a clear increase in WQP due to fouling is observed. This can be explained by an effective pore closure by the foulants.

With ferric chloride addition, the WQP changes significantly for the more open membranes due to a higher rejection of colloids and organics. These results are presented in Table 6.

\section{Membrane and Energy Cost Estimation}

The membrane materials selected for cost estimates are the MF PVDF (62.5 US $\left.\$ \mathrm{~m}^{2}\right)$, the UF CA (16.7 US $\left.\$ \mathrm{~m}^{2}\right)$, and the NF PA $\left(20.8 \mathrm{US} \$ / \mathrm{m}^{2}\right)$. Costs were provided by Leslie (1999) and originate from comparative studies at Water Factory 21 in Orange County (USA). Values are tabulated in Table 7. The selection was based on the compan despite other materials being installed currently. For polypropylene the cost will be about one third of the estimate and possibly lower for a submerged membrane system (Johnson (1999)). Membrane life can be estimated in the order of five years, thus the membrane cost will be a maintenance cost as well as an investment cost.

Membrane cost was estimated from fluxes obtained in experiments and the membrane area required to produce $1000 \mathrm{~m}^{3} / \mathrm{d}$ product water. Figure 9 shows the membrane cost as a function of WQP (values were shown in Table 4) based on pure water fluxes.

Costs for the MF and open UF membranes are comparable. For tight UF membranes MWCO 1-5 $\mathrm{kDa}$ ) the costs increase to unacceptable levels and are in fact lower for the TFC-SR and -S membranes. The CA-UF membrane lies well in the UF range and is cost wise extremely competitive given the high WQP. It should be noted that for applications requiring turbidity removal only (WQP of 50 to 100) MF or loose UF have a major cost advantage.

When fluxes of fouled membranes are considered (Figure 10 and Table 5), the cost increases, but the overall trend is similar. Membrane costs for the TFC-S and -ULP membranes increase significantly compared to pure water due to the high salt rejection which causes a flux reduction due to an osmotic effect. The high salt rejections of these membranes are not usually required for surface water applications.

Cost values for membranes fouled with ferric chloride coagulant are shown in Table 6. With ferric chloride pretreatment the cost becomes prohibitive for MF operated at low flux and high ferric chloride dosage (see also no 3 in Figure 11). This is due to the larger membrane area required at low flux.

Ferric chloride increases the WQP for MF and UF and MF moves into the area of UF (see nos 1,2,3 and 4; the areas were defined previously based on rejection without pretreatment).

At the low dosage cost is lowest at the highest initial fluxes. For the higher dosage (see no 4) the cost is not determined by initial flux, but fouling becomes the crucial criterion. At identical WQP the $30 \mathrm{kDa}$ UF membrane is lowest in cost, followed by low flux MF, then the $100 \mathrm{kDa}$ and $10 \mathrm{kDa}$ membranes.

The membrane cost for NF (TFC-SR) is comparable at a much higher WQP. Membrane costs are reduced with ferric chloride addition as fouling is reduced as was shown in Fioure 7. However, the ferric chloride would add to the overall treatment costs.

\section{If one further considers the cost of ferric chloride (see}

Table 8) and the energy cost (see Table 9) the advantage of a process which does not require chemical pretreatment becomes even more important. Recovery is defined as the product to feed volume ratio. It is limited by backwash and cleaning volumes for MF and UF, and by the maximum concentration in a module for NF and RO.

Energy costs are comparable or lower than the cost of ferric chloride (with the exception of RO due to osmotic effects due to high salt rejection). This does not include sludge treatment or the 
Schäfer, A.I. ; Fane, A.G. ; Waite, T.D. (2001) Cost Factors and Chemical Pretreatment Effects in the Membrane Filtration of Waters containing Natural Organic Matter, Water Research 35, 6 , $1509-1517$. doi:10.1016/S0043-1354(00)00418-8

consideration that energy can be provided from a renewable source which further supports the environmental argument for using NF when organic removal is important.

Finally, Table 10 shows a comparison of costs which originate from membranes, energy and chemicals addition. Costs are in US\$ per $1000 \mathrm{~m}^{3}$. Membrane costs are based on a membrane life of 5 years.

The cost range for MF and open UF is the range of without pretreatment at the lower end and With lowest cost ferric chloride at a dosage of $100 \mathrm{mgL}^{-1}$ at the upper end. Costs will increase if higher quality coagulant is used or if the plant is at some distance to the ferric chloride supplier. The results show that chemical pretreatment costs effect treatment costs considerably and $\mathrm{NF}$ appears to be the choice for a stable water quality and cost.

\section{CONCLUSIONS}

This study demonstrates that membranes with tighter pore sizes are superior to more porous membranes in terms of rejection and membrane costs where such costs include capital and maintenance costs of the membrane installation, costs of chemicals used for pretreatment and energy costs.

This contradicts the conventional belief that a hybrid process consisting of chemical treatment and MF is cheaper than NF. While NF produces waters with a guaranteed and relatively stable quality, the effectiveness of chemical pretreatment depends strongly on the organic type and solution chemistry. Costs for chemical pretreatment are above the energy costs for NF if a substantial amount of organics is to be removed.

However, it is appreciated that for an application only requiring removal of turbidity (including microorganisms) MF or loose UF have a clear cost advantage.

A cost comparison of chemicals addition and energy consumption revealed that the additional energy required to operate NF is cheaper than the chemicals required to achieve a comparable organics removal with MF. While a more complete analysis is required including a complete assessment of environmental impact the results obtained should encourage some rethinking of current water treatment practices.

\section{ACKNOWLEDGEMENTS}

The Cooperative Research Centre for Water Quality \& Treatment (Adelaide, Australia) is thanked for project funding. The assistance of Martina Fischer, Ursula Schwicker and Emmanuelle Aoustin with experimental work is appreciated.

Material support from Fluid Systems (now Koch Membrane Systems, San Diego, USA) and Millipore (Australia) is also acknowledged.

\section{REFERENCES}

Aoustin, E., Schäfer, A.I., Fane, A.G. and Waite, T.D. (2000), Effect of humic substance and colloid interactions on ultrafiltration behaviour Separation and Purification Technology, (in press).

Childress, A.E. and Elimelech, M. (1996), Effect of solution chemistry on the surface charge of polymeric reverse osmosis and nanofiltration membranes Journal of Membrane Science 119 253268.
Crozes, G., White, P. and Marshall, M. (1995) Enhanced coagulation: its effect on NOM removal and chemical costs Journal AWWA 87 78-89.

Fane, A.G. (1996) Membranes for water production and waste water reuse Desalination 106 1-9.

Ho, W.S.W. and Sirkar, K.K. (1992) Membrane Handbook, Chapman \& Hall, New York.

Jacangelo, J.G., Adham, S.S. and Laîné, J.-M. (1995) Mechanisms of Cryptosporidium, Giardia, and MS2 virus removal by MF and UF Journal AWWA 07 107-121.

Johnson, W.T. (1999) Recent advances in microfiltration for drinking water treatment AWWA Annual Meeting Chicago June '99.

Leslie, G. personal communication (10/1999).

Schäfer, A.I. (1999) Natural organics removal using membranes, PhD Thesis, University of NSW, Chemical Engineering Sydney, ISBN 0733406521.

Schäfer, A.I., Fane, A.G. and Waite, T.D. (1998) Nanofiltration of natural organic matter: Removal, fouling and the influence of multivalent ions Desalination 118 109-122.

Schäfer, A.I., Schwicker, U., Fischer, M.M., Fane, A.G. and Waite, T.D. (2000) Microfiltration of Colloids and Natural Organic Matter J Membrane Science 171(2) 151-172.

Takigawa, D., personal communication (07/1999).

Worch, E. (1993) A new equation for the calulation of diffusion coefficients of solutes (Eine neue Gleichung zur Berechnung von Diffusionskoeffizienten gelöster Stoffe) Vom Wasser 81 289-297. 
Schäfer, A.I. ; Fane, A.G. ; Waite, T.D. (2001) Cost Factors and Chemical Pretreatment Effects in the Membrane Filtration of Waters containing Natural Organic Matter, Water Research 35, 6, $1509-1517$. doi:10.1016/S0043-1354(00)00418-8

\section{FIGURE CAPTIONS}

Figure 1 Rejection of DOC as a function of calculated pore diameter (see Table 2 for membrane characterisation). Experimental conditions $\mathrm{pH} 7-8,5-15 \mathrm{mgL}^{-1}$ as DOC organics, $0.5 \mathrm{mM} \mathrm{CaCl}_{2}, 1$ $\mathrm{mM} \mathrm{NaHCO}$, stirred at 270 to $400 \mathrm{rpm}$, transmembrane pressures 1 bar (MF and UF 30-100 kDa), 3 bar (UF 1-10 kDa), and 5 bar (NF).

Figure $2 \mathrm{UV}_{254}$ rejection as a function of pore diameter. The DOC curve is adapted from Figure 1. Experimental conditions as in Figure 1.

Figure 3 Rejection at fouling conditions $\left(12.5 \mathrm{mgL}^{-1}\right.$ as DOC IHSS HA, $2.5 \mathrm{mM} \mathrm{CaCl}_{2}, \mathrm{pH}$ 8) as a function of pore diameter. The line graphs are rejection results of unfouled membranes adapted from Figure 1 and Figure 2.

Figure 4 DOC rejection as a function of pore diameter with coagulation pretreatment compared to rejection with no pretreatment (shown as a line). Experimental conditions $\mathrm{pH} 7-8,5-15 \mathrm{mgL}^{-1}$ as DOC organics, $0.5 \mathrm{mM} \mathrm{CaCl}_{2}, 1 \mathrm{mM} \mathrm{NaHCO}_{3}$.

Figure 5 Ferric chloride addition in microfiltration (GVWP membrane, $2.5 \mathrm{mM} \mathrm{CaCl}_{2}, \mathrm{pH} 7-8,1 \mathrm{mM}$ $\mathrm{NaHCO}_{3}, 20 \mathrm{mM} \mathrm{NaCl}, 5 \mathrm{mgL}^{-1}$ DOC IHSS HA).

Figure 6 Ferric chloride addition in ultrafiltration $(100 \mathrm{kDa}, 30 \mathrm{kDa}$ and $10 \mathrm{kDa}$ membranes, $0.5 \mathrm{mM}$ $\mathrm{CaCl}_{2}, \mathrm{pH} 7-8,1 \mathrm{mM} \mathrm{NaHCO}, 20 \mathrm{mM} \mathrm{NaCl}, 5 \mathrm{mgL}^{-1}$ DOC IHSS FA).

Figure 7 Ferric chloride addition at fouling conditions in nanofiltration (TFC-SR membrane, $2.5 \mathrm{mM}$ $\mathrm{CaCl}_{2}, \mathrm{pH} 7-8,1 \mathrm{mM} \mathrm{NaHCO}, 20 \mathrm{mM} \mathrm{NaCl}, 12.5 \mathrm{mgL}^{-1}$ DOC IHSS HA).

Figure 8 Water quality parameter as a function of clean membrane pore diameter. Values adapted from Table 4

Figure 9 Membrane cost per $1000 \mathrm{~m}^{3} / \mathrm{d}$ capacity at clean water conditions over water quality parameter Membranes are 1-GVWP at high flux, 2-GVWP at low flux, 3-100kDa UF, 4-30 kDa UF, 5-10 kDa UF, 6-5 kDa UF, 7-3 kDa UF, 8-1 kDa UF, 9-CA-UF, 10-TFC-SR, 11-TFC-S, 12-TFC-ULP.

Figure 10 Membrane cost per $1000 \mathrm{~m}^{3} / \mathrm{d}$ capacity at fouling conditions over water quality parameter. Membranes are 1-GVWP at high flux, 2-GVWP at low flux, 3-100kDa UF, 4-30 kDa UF, 5-10 kDa UF, 6-5 kDa UF, 7-3 kDa UF, 8-1 kDa UF, 9-CA-UF, 10-TFC-SR, 11-TFC-S, 12-TFC-ULP.

Figure 11 Membrane cost per $1000 \mathrm{~m}^{3} / \mathrm{d}$ capacity as a function of WQP. Membranes with no ferric chloride as shown in Figure 9. 1-GVWP high flux \& low dose, 100kDa UF and 30kDa UF, 2- GVWW low flux \& low dose and $10 \mathrm{kDa}$ UF, 3-GVWP low flux, 4-30kDa UF $<$ GVWWP low flux and high dose $<100 \mathrm{kDa}$ UF $<10 \mathrm{kDa}$ UF, 5 -TFC-SR.

\section{FIGURES}

Figure 1

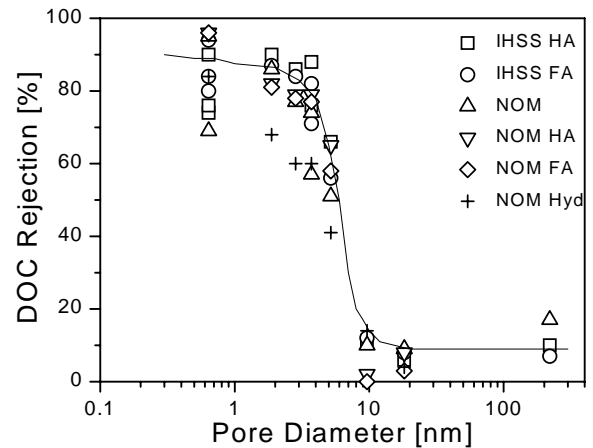

Figure 2

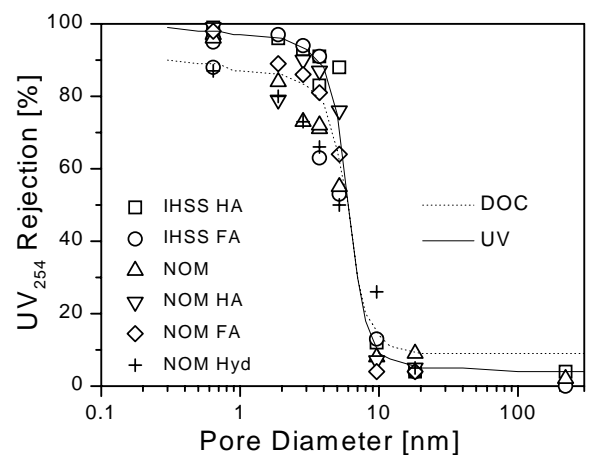


Schäfer, A.I. ; Fane, A.G. ; Waite, T.D. (2001) Cost Factors and Chemical Pretreatment Effects in the Membrane Filtration of Waters containing Natural Organic Matter, Water Research 35, 6, $1509-1517$. doi:10.1016/S0043-1354(00)00418-8

Figure 3
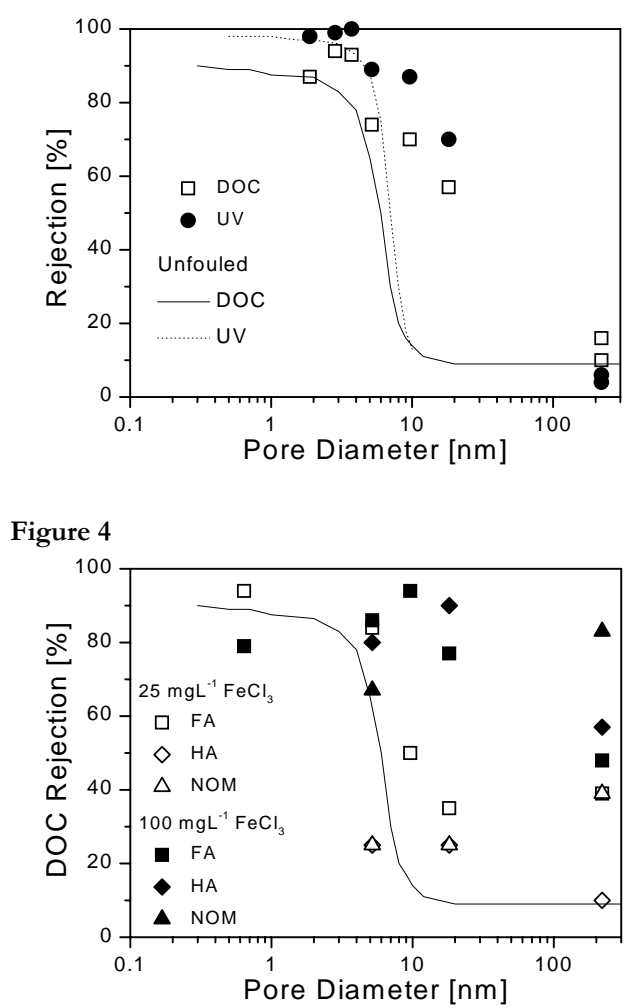

Figure 5

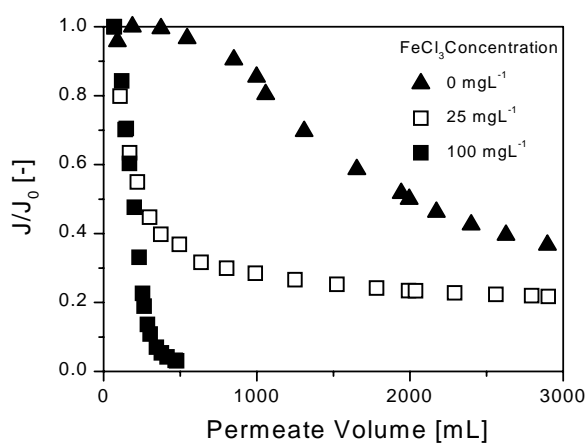

Figure 6

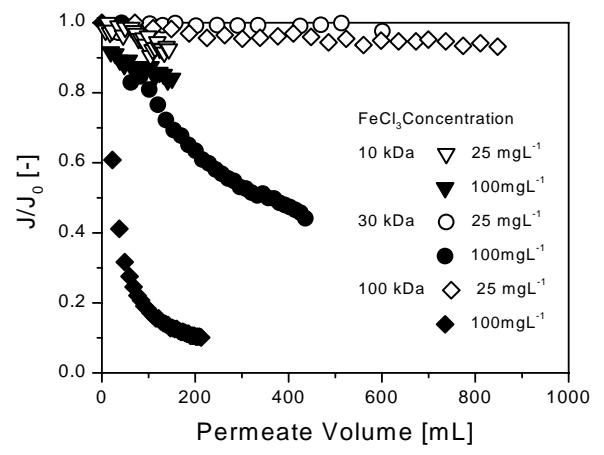

Figure 7

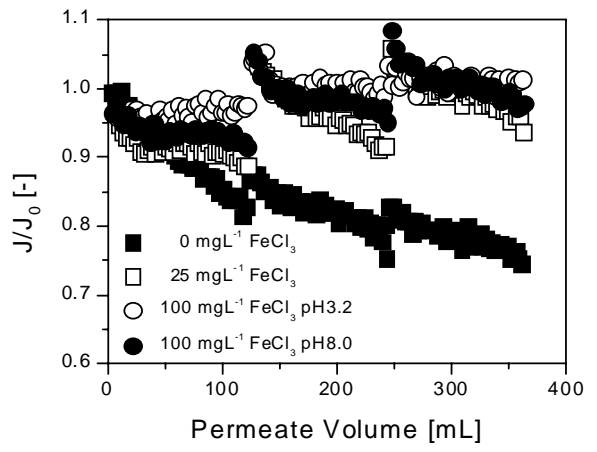


Schäfer, A.I. ; Fane, A.G. ; Waite, T.D. (2001) Cost Factors and Chemical Pretreatment Effects in the Membrane Filtration of Waters containing Natural Organic Matter, Water Research 35, 6, $1509-1517$. doi:10.1016/S0043-1354(00)00418-8

Figure 8

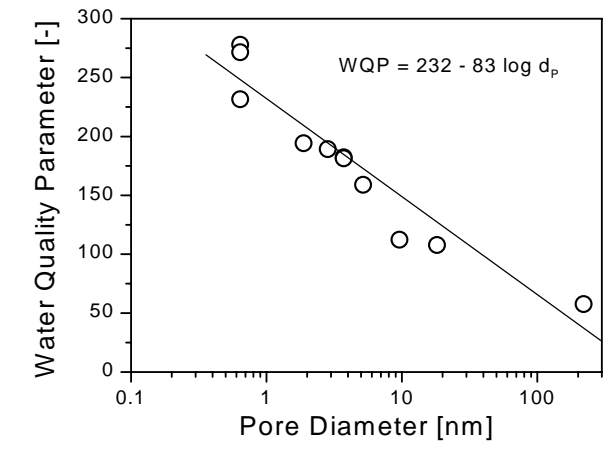

Figure 9

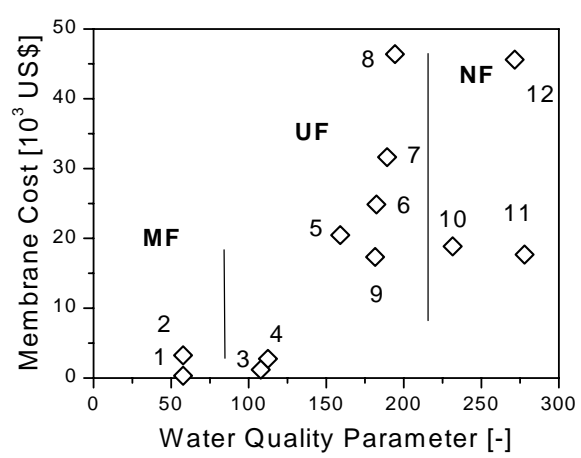

Figure 10

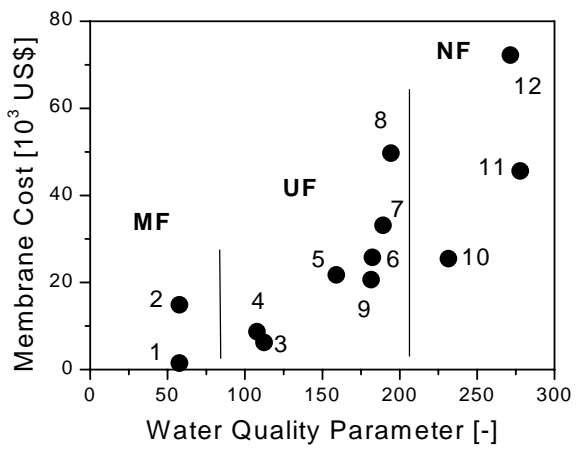

Figure 11

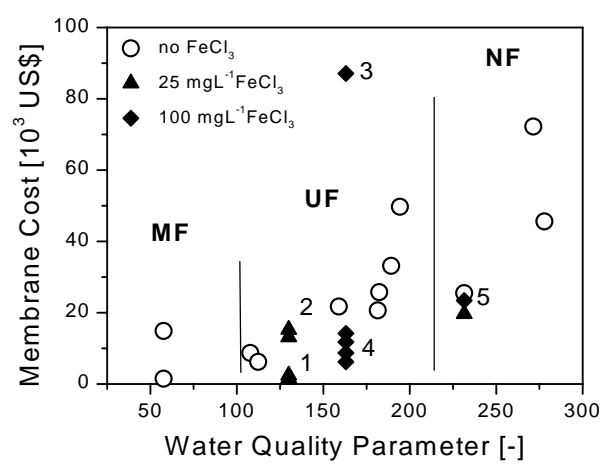


Schäfer, A.I. ; Fane, A.G. ; Waite, T.D. (2001) Cost Factors and Chemical Pretreatment Effects in the Membrane Filtration of Waters containing Natural Organic Matter, Water Research 35, 6, $1509-1517$. doi:10.1016/S0043-1354(00)00418-8

\section{TABLES}

Table 1 Solution composition as used in experiments.

\begin{tabular}{lcccccc}
\hline & $\begin{array}{c}\mathrm{pH} \\
{[-]}\end{array}$ & $\begin{array}{c}\mathrm{NaHCO}_{3} \\
{[\mathrm{mM}],\left[\mathrm{mgL}^{-1}\right]}\end{array}$ & $\begin{array}{c}\mathrm{CaCl}_{2} \\
{[\mathrm{mM}],\left[\mathrm{mgL}^{-1}\right]}\end{array}$ & $\begin{array}{c}\mathrm{NaCl} \\
{[\mathrm{mM}],\left[\mathrm{mgL}^{-1}\right]}\end{array}$ & $\begin{array}{c}\mathrm{Natural} \mathrm{Organics}^{1} \\
{\left[\mathrm{mgL}^{-1} \text { as DOC }\right]}\end{array}$ & $\begin{array}{c}\text { Inorganic } \\
\text { Colloids }^{2}\left[\mathrm{mgL}^{-1}\right]\end{array}$ \\
\hline $\begin{array}{l}\text { Rejection } \\
\begin{array}{l}\text { Experiments } \\
\text { Fouling }\end{array}\end{array}$ & $7-8$ & 1,84 & $0.5,56$ & 20,2935 & $5-12.5$ & 10 \\
Experiments & $7-8$ & 1,84 & $2.5,280$ & 20,2935 & $5-12.5$ & 10 \\
\hline
\end{tabular}

Experiments

Natural organics were humic acid, fulvic acid, natural organic matter or fractions of those.

${ }^{2}$ Inorganic colloids were monodispersed, spherical hematite colloids (diameters 40, 75, 250 and $500 \mathrm{~nm}$ ).

Table 2 Pure water membrane characteristics (flux, permeability, applied transmembrane pressure, membrane resistance, molecular weight cut-off (MWCO) and pore diameter) of the MF, UF and NF membranes used in experiments.

\begin{tabular}{|c|c|c|c|c|c|c|c|}
\hline Process & Membrane & $\begin{array}{c}\text { Pure Water } \\
\text { Flux } \\
{\left[\mathrm{Lm}^{-2} \mathrm{~h}^{-1}\right]}\end{array}$ & $\begin{array}{c}\text { Water } \\
\text { Permeability } \\
{\left[\mathrm{Lm}^{-2} \mathrm{~h}^{-1} \mathrm{bar}^{-1}\right]}\end{array}$ & $\begin{array}{l}\text { Pressure } \\
\text { [bar] }\end{array}$ & $\begin{array}{c}\text { Membrane } \\
\text { Resistance } \\
{\left[\mathrm{m}^{-1}\right]}\end{array}$ & $\begin{array}{c}\text { MWCO } \\
{[\mathrm{kDa}]}\end{array}$ & $\begin{array}{c}\text { Pore } \\
\text { Diameter } \\
{[\mathrm{nm}]}\end{array}$ \\
\hline MF & GVWP & $7968 \pm 288$ & 7968 & 1 & $4.51 \cdot 10^{7}$ & e & $220^{*}$ \\
\hline MF & GVHP & $7803 \pm 308$ & 7803 & 1 & $4.60 \cdot 10^{7}$ & - & $220^{*}$ \\
\hline UF & PLHK & $1320 \pm 40$ & 1320 & 1 & $0.03 \cdot 10^{10}$ & $100^{*}$ & 18.20 \\
\hline UF & PLTK & $390 \pm 20$ & 390 & 1 & $0.09 \cdot 10^{10}$ & $30^{*}$ & 9.62 \\
\hline UF & PLGC & $65 \pm 5$ & 21.7 & 3 & $1.66 \cdot 10^{10}$ & $10^{*}$ & 5.18 \\
\hline UF & PLCC & $28 \pm 3$ & 9.3 & 3 & $3.85 \cdot 10^{10}$ & $5^{*}$ & 3.72 \\
\hline UF & PLBC & $22 \pm 2$ & 7.3 & 3 & $4.90 \cdot 10^{10}$ & $3^{*}$ & 2.84 \\
\hline UF & PLAC & $15 \pm 2$ & 5.0 & 3 & $7.18 \cdot 10^{10}$ & $1^{*}$ & 1.88 \\
\hline NF & CA-UF & $49.9 \pm 4.2$ & 10.0 & 5 & $3.6 \cdot 10^{10}$ & $5^{\#}$ & 3.72 \\
\hline NF & TFC-SR & $45.8 \pm 6.1$ & 9.2 & 5 & $3.9 \cdot 10^{10}$ & $<0.18^{\#}$ & $<0.64$ \\
\hline NF & TFC-S & $49.4 \pm 5.9$ & 9.9 & 5 & $3.6 \cdot 10^{10}$ & $<0.18^{\#}$ & $<0.64$ \\
\hline NF & TFC-ULP & $19.4 \pm 2.6$ & 3.9 & 5 & $9.3 \cdot 10^{10}$ & $<0.18^{\#}$ & $<0.64$ \\
\hline
\end{tabular}

Fluid Systems using lactose (1999))

Table 3 Cation rejection as a function of membrane pore size in the absence of organics $(0.5 \mathrm{mM}$ $\left.\mathrm{CaCl}_{2}, \mathrm{pH} 7-8,1 \mathrm{mM} \mathrm{NaHCO}, 20 \mathrm{mM} \mathrm{NaCl}\right)$.

\begin{tabular}{lcccccc}
\hline Pore Size $[\mathrm{nm}]$ & 220 & 18.2 & 9.6 & 5.2 & 3.7 & 2.8 \\
\hline Sodium [\%] & 0 & 0 & 0 & 0 & 0 & 0 \\
Calcium [\%] & 0 & 0 & 2.8 & 2.6 & 2.0 & 13.6 \\
\hline Pore Size [nm] & 1.9 & 3.7 & $<0.64$ & $<0.64$ & $<0.64$ & \\
Sodium [\%] & 0 & 12.6 & 37.4 & 82.0 & 85.0 & \\
Calcium [\%] & 13.2 & 14.4 & 67.6 & 94.4 & 90.4 & \\
\hline
\end{tabular}

Table 4 Water quality criteria for process evaluation and water quality parameter. The numbers are fractions of the rejection achieved. The sum of each parameter suite of 100 corresponds to a rejection of $100 \%$ of all fractions. Experimental conditions were $\mathrm{pH} 7-8,5-15 \mathrm{mgL}^{-1}$ organic as DOC, $0.5 \mathrm{mM}$ $\mathrm{CaCl}_{2}$ (except for $\mathrm{MF}$ where calcium concentration is $2.5 \mathrm{mM}$ ). The values will depend on time (or permeate volume) and stirring regime. Membrane cost estimate based on pure water flux and a plant capacity of $1000 \mathrm{~m}^{3} / \mathrm{d}$.

\begin{tabular}{|c|c|c|c|c|c|c|c|c|c|c|c|}
\hline & \multicolumn{4}{|c|}{ Colloids } & \multicolumn{3}{|c|}{ DOC } & \multicolumn{2}{|c|}{ Ions } & \multirow{2}{*}{$\begin{array}{c}\text { TOTAL } \\
\begin{array}{c}\text { WQP } \\
(300 \mathrm{max})\end{array}\end{array}$} & \multirow{2}{*}{$\begin{array}{c}\text { Membrane } \\
\text { Cost Clean } \\
\text { [US\$] }\end{array}$} \\
\hline & $\begin{array}{l}40 \\
\mathrm{~nm}\end{array}$ & $\begin{array}{c}75 \\
\mathrm{~nm}\end{array}$ & $\begin{array}{l}250 \\
\mathrm{~nm}\end{array}$ & $\begin{array}{l}500 \\
\mathrm{~nm}\end{array}$ & $\mathrm{HA}$ & FA & NOM & $\mathrm{Na}^{+}$ & $\mathrm{Ca}^{2+}$ & & \\
\hline MF GVWP & 0 & 2.1 & 20.8 & 23.3 & 3.4 & 2.4 & 5.7 & 0 & 0 & 58 & 325 \\
\hline UF $100 \mathrm{kDa}$ & 25 & 25 & 25 & 25 & 2.0 & 2.8 & 3.0 & 0 & 0 & 108 & 1185 \\
\hline UF 30 kDa & 25 & 25 & 25 & 25 & 3.7 & 4.0 & 3.3 & 0 & 1.4 & 112 & 2740 \\
\hline UF $10 \mathrm{kDa}$ & 25 & 25 & 25 & 25 & 22.0 & 18.7 & 17.0 & 0 & 1.3 & 159 & 20466 \\
\hline UF 5 kDa & 25 & 25 & 25 & 25 & 29.3 & 27.3 & 24.7 & 0 & 1.0 & 182 & 24851 \\
\hline UF $3 \mathrm{kDa}$ & 25 & 25 & 25 & 25 & 28.7 & 28.0 & 25.7 & 0 & 6.8 & 189 & 31629 \\
\hline UF 1 kDa & 25 & 25 & 25 & 25 & 30.0 & 29.0 & 28.7 & 0 & 6.6 & 194 & 46389 \\
\hline NF CA-UF & 25 & 25 & 25 & 25 & 25.3 & 23.6 & 19.1 & 6.3 & 7.2 & 182 & 17333 \\
\hline NF TFC-SR & 25 & 25 & 25 & 25 & 24.7 & 31.3 & 23.0 & 18.7 & 33.8 & 232 & 18841 \\
\hline NF TFC-S & 25 & 25 & 25 & 25 & 30.0 & 27.9 & 31.8 & 41.0 & 47.2 & 278 & 17687 \\
\hline NF TFC-ULP & 25 & 25 & 25 & 25 & 25.2 & 26.8 & 31.8 & 42.5 & 45.2 & 272 & 45614 \\
\hline
\end{tabular}

Table 5 Water quality parameter for fouling conditions $\left(2.5 \mathrm{mM} \mathrm{CaCl}_{2}\right.$, $\mathrm{pH} 7-8$, IHSS HA). Plant capacity for cost estimate $1000 \mathrm{~m}^{3} / \mathrm{d}$.

\begin{tabular}{lcccccccc}
\hline \multicolumn{1}{c}{ Process } & $\begin{array}{c}\text { Total } \\
\text { Colloids }\end{array}$ & DOC & UV $_{254 n m}$ & $\mathrm{Ca}^{2+}$ & $\mathrm{Na}^{+}$ & $\begin{array}{c}\text { WQP } \\
{[-]}\end{array}$ & $\begin{array}{c}\text { Membrane Cost } \\
\text { Clean [US\$] }\end{array}$ & $\begin{array}{c}\text { Membrane Cost } \\
\text { Fouled [US\$] }\end{array}$ \\
\hline MF GVWP & 46 & 10 & 4 & 0 & 0 & 56 & 325 & 1488 \\
MF GVWP & 46 & 10 & 4 & 0 & 0 & 56 & 3250 & 14880 \\
UF 100kDa & 100 & 57 & 70 & 0 & 0 & 157 & 1185 & 8698 \\
UF 10 kDa & 100 & 70 & 87 & 6 & 4 & 175 & 20466 & 21745 \\
NF CA-UF & 100 & 74 & 89 & 21 & 20 & 195 & 17333 & 20635 \\
NF TFC-SR & 100 & 93 & 100 & 55 & 24 & 233 & 18841 & 25490 \\
NF TFC-S & 100 & 94 & 99 & 96 & 80 & 282 & 17687 & 45614 \\
NF TFC-ULP & 100 & 87 & 98 & 98 & 91 & 282 & 45614 & 72222 \\
\hline
\end{tabular}

flux values corrected for low flux by a foctor 10 from experimental value (1750 to $\left.175 \mathrm{Lm}^{-2} \mathrm{~h}^{-1}\right)$ due to lower permeate pressure drop of flat sheet membranes. 
Schäfer, A.I. ; Fane, A.G. ; Waite, T.D. (2001) Cost Factors and Chemical Pretreatment Effects in the Membrane Filtration of Waters containing Natural Organic Matter, Water Research 35, 6 , $1509-1517$. doi:10.1016/S0043-1354(00)00418-8

Table 6 Water quality parameter for pretreatment with ferric chloride $(2.5 \mathrm{mM} \mathrm{CaCl}, \mathrm{pH} 7-8$, IHSS HA). Plant capacity for cost estimate $1000 \mathrm{~m}^{3} / \mathrm{d}$.

\begin{tabular}{|c|c|c|c|c|c|c|c|}
\hline \multirow{3}{*}{ Process } & \multirow{3}{*}{$\begin{array}{c}\text { Total } \\
\text { Colloids }\end{array}$} & \multicolumn{3}{|l|}{ Rejection [\%] } & \multicolumn{3}{|c|}{ Quality and Cost } \\
\hline & & DOC & \multirow[t]{2}{*}{$\mathrm{Ca}^{2+}$} & \multirow[t]{2}{*}{$\mathrm{Na}^{+}$} & \multirow{2}{*}{$\begin{array}{c}\text { WQP } \\
{[-]}\end{array}$} & \multirow{2}{*}{$\begin{array}{c}\text { Membrane } \\
\text { Cost Clean } \\
\text { [US\$] }\end{array}$} & \multirow{2}{*}{$\begin{array}{l}\text { Membrane Cost Fouled [US\$] } \\
25 \mathrm{mgL}^{-1} / 100 \mathrm{mgL}^{-1} \mathrm{FeCl}_{3}\end{array}$} \\
\hline & & $25 \mathrm{mgL}^{-1} / 100 \mathrm{mgL}^{-1} \mathrm{FeCl}_{3}$ & & & & & \\
\hline MF GVWP & 100 & $10-39 / 48-83^{*}$ & 0 & 0 & $110-183$ & 325 & 1525 / 8710 \\
\hline MF GVWP ${ }^{\#}$ & 100 & $10-39$ / 48-83 & 0 & 0 & $110-183$ & 3250 & $15250 / 87100$ \\
\hline UF 100kDa & 100 & $35-90$ / 77 & 0 & 0 & $135-177$ & 1185 & $1183 / 11794$ \\
\hline UF $30 \mathrm{kDa}$ & 100 & $50 / 94$ & 0 & 0 & $150-194$ & 2740 & 2433 / 6213 \\
\hline UF 10 kDa & 100 & $67-84 / 86$ & 6 & 4 & 172-191 & 20466 & 13129 / 14201 \\
\hline NF TFC-SR & 100 & $94 / 79$ & $83-99$ & 3-43 & $222-265$ & 18841 & 19697 / 23424 \\
\hline
\end{tabular}

range depending on organic type.

flux values corrected for low flux by a factor 10 from experimental value (1750 to $\left.175 \mathrm{Lm}^{-2} \mathrm{~h}^{-1}\right)$ due to lower permeate pressure drop of flat sheet membranes.

Table 7 Membrane cost based on Water Factory 21 Experience (Leslie (1999)).

\begin{tabular}{lccc}
\hline Process & $\begin{array}{c}\text { Module Size } \\
{\left[\mathrm{m}^{2}\right]}\end{array}$ & $\begin{array}{c}\text { Average Module } \\
\text { Cost [US\$] }\end{array}$ & $\begin{array}{c}\text { Membrane Cost } \\
{\left[\mathrm{US} \$ / \mathrm{m}^{2}\right]}\end{array}$ \\
\hline MF Polypropylene & 31 & 650 & 21.0 \\
MF PVDF & 40 & 2500 & 62.5 \\
UF CA & 90 & 1500 & 16.7 \\
NF Polyamide & 48 & $750-1000$ & $15.6-20.8$ \\
RO Polyamide & 50 & $<500$ & $<10$ \\
RO CA & 50 & $<500$ & $<10$ \\
\hline
\end{tabular}

Table 8 Ferric chloride cost as a function of dosage for a $1000 \mathrm{~m}^{3} /$ day plant capacity. Range of costs of ferric chloride used was 0.29 to $7.1 \mathrm{US} \$ / \mathrm{kg}$ depending on largely location of water treatment plant and coagulant quality.

\begin{tabular}{|c|c|c|}
\hline & \multicolumn{2}{|c|}{$\begin{array}{l}\text { Ferric Chloride Dosage as FeCl } \\
{\left[\mathrm{mgL}^{-1}\right]}\end{array}$} \\
\hline Ferric Chloride & 25 & 100 \\
\hline Consumption $[\mathrm{kg} / \mathrm{d}]$ & 25 & 100 \\
\hline Cost [US\$/d] & 7.3-177.5 & 29.4-710.0 \\
\hline Cost [US\$ $\left./ \mathrm{m}^{3}\right]$ & $0.007-0.18$ & $0.029-0.71$ \\
\hline
\end{tabular}

Table 9 Typical recoveries, transmembrane pressures, power requirements, consumption and resulting energy costs based on applied pressures with an overall motor/pump efficiency of $40 \%$. Assumed energy cost $0.05 \mathrm{US} \$ / \mathrm{kWh}$.

\begin{tabular}{ccccc}
\hline & $\begin{array}{c}\text { Recovery } \\
{[\%]}\end{array}$ & $\begin{array}{c}\text { Pressure } \\
{[\mathrm{kPa}]}\end{array}$ & $\begin{array}{c}\text { Consumption } \\
{[\mathrm{kWh} / \mathrm{d}]}\end{array}$ & $\begin{array}{c}\text { Energy cost } \\
{\left[\mathrm{US} \$ / \mathrm{m}^{3}\right]}\end{array}$ \\
\hline MF & $90-98$ & 100 & $77.5-70.8$ & $0.004-0.0035$ \\
UF & $90-98$ & 100 & $77.5-70.8$ & $0.004-0.0035$ \\
UF & $90-98$ & 300 & $231.5-212.5$ & $0.012-0.011$ \\
NF & $75-95$ & 500 & 463.365 .35 & $0.023-0.018$ \\
RO & $50-80$ & 1000 & $1389-868.3$ & $0.070-0.043$ \\
\hline
\end{tabular}

Table 10 Comparison of WQP as well as membrane, energy and chemical costs for selected membranes. It has been assumed that membranes last for 5 years.

\begin{tabular}{lcccccccc}
\hline $\begin{array}{l}\text { COSTS } \\
\text { [US\$1000m }\end{array}$ & WQP [ - ] & $\begin{array}{c}\text { Clean } \\
\text { Membrane }\end{array}$ & $\begin{array}{c}\text { Fouled } \\
\text { Membrane }\end{array}$ & $\begin{array}{c}\mathrm{FeCl}_{3} \text { Fouled } \\
\text { Membrane }\end{array}$ & $\begin{array}{c}\text { Energy } \\
\text { Cost }\end{array}$ & $\begin{array}{c}\mathrm{FeCl}_{3} \text { Cost } \\
25 \mathrm{mLL}^{-1}\end{array}$ & $\begin{array}{c}\mathrm{FeCl}_{3} \text { Cost }_{10} \\
100 \mathrm{mLL}^{-1}\end{array}$ & Total $^{*}$ \\
\hline MF GVWWP & $58-183$ & 0.18 & 0.82 & 4.88 & $1.5-1.4$ & $7.34-177.5$ & $29.4-710$ & $2.2-35.8$ \\
MF GVWP & $58-183$ & 1.78 & 8.15 & 47.7 & $0.15-0.14$ & $7.34-177.5$ & $29.4-710$ & $8.3-77.3$ \\
UF 100 kDa & $108-177$ & 0.65 & 4.77 & 6.46 & $1.5-1.4$ & $7.34-177.5$ & $29.4-710$ & $6.2-37.4$ \\
UF 30 kDa & $112-194$ & 1.50 & 3.40 & 3.40 & $1.5-1.4$ & $7.34-177.5$ & $29.4-710$ & $4.8-34.3$ \\
UF 1 10Da & $159-191$ & 11.2 & 11.9 & 7.78 & $4.6-4.2$ & $7.34-177.5$ & $29.4-710$ & $16.1-41.8$ \\
UF 5 kDa & 182 & 13.6 & 14.1 & - & $4.6-4.2$ & - & - & 18.5 \\
UF kDa & 189 & 17.3 & 18.2 & - & $4.6-4.2$ & - & - & 22.6 \\
UF 1 kDa & 194 & 25.4 & 27.2 & - & $4.6-4.2$ & - & - & 31.6 \\
NF CA-UF & 182 & 9.5 & 11.3 & - & $9.3-9.7$ & - & - & 20.8 \\
NF TFC-SR & 232 & 10.3 & 14.0 & - & $9.3-9.7$ & - & - & 23.5 \\
NF TFC-S & 278 & 9.7 & 25.0 & - & $9.3-9.7$ & - & - & 34.5 \\
NF TFC-ULP & 272 & 25.0 & 39.6 & - & $9.3-9.7$ & - & - & 49.1 \\
\hline \multicolumn{7}{l}{ \# Flux and pressure reduced by a factor of 10. }
\end{tabular}

Cox and pressure reduced by a factor of 10

quality and cost. Range is cost without pretreatment to pretreatment with lowest cost ferric chloride at a dosage of $100 \mathrm{mgL}^{-1}$. 